\title{
TURNAROUND MANAGEMENT AS A CORPORATE RENEWAL MODEL
}

\author{
Ljiljana Jeremić $^{1 \star}$, Marko Fabris ${ }^{2}$ \\ ${ }^{1}$ Singidunum University, Faculty of Business in Begrade, 32 Danijelova Street, Belgrade, Serbia \\ ${ }^{2}$ PricewaterhouseCoopers Consulting d.o.o., Airport City, Omladinskih Brigada 88a, Belgrade, Serbia
}

\begin{abstract}
:
In the conditions of the global financial crisis, a large number of companies has encountered significant losses, and many have experienced an economic collapse. The altered market conditions, insolvency and internal weaknesses call for comprehensive changes in business activities. Turnaround management, as a corporate renewal model, has proven to be a good approach to implementing a recovery plan for companies facing significant financial and structural difficulties. A considerable number of companies operating in different industries have used turnaround management as a corporate renewal model. The authors shall present one such model that has produced favourable financial results.
\end{abstract}

\author{
Key words: \\ turnaround management, \\ restructuring, \\ recovery.
}

\section{INTRODUCTION}

The debt crisis has three stages: a decline in business activity and revenue; liquidity problems; and lack of cash. All these difficulties call for adaptability. Such difficulties are resolved in practice through variable costs and company headcount reduction (Khandwalla, 1998). Unilateral measures in overcoming business challenges are usually not sufficient, especially when a company is facing internal issues and external problems such as the economic crisis. The depth and intensity of the recent global crisis may be understood if we take a look at statistical data showing that in 2009, uncollectable accounts receivable amounted to USD 3.6 billion (Gilson, 2010, p. 18). A significant decline in business activity as well as collection problems have had an impact on the solvency of companies and their ability to settle obligations towards suppliers and banks. Practice has shown that companies operating in the region have started dealing with liquidity issues only after banks have put pressure on them, and usually this is too late. The situation is pretty much the same in Serbia. Official statistics show that approximately EUR 3.7 billion, or 23 percent of all granted loans fall within the category of non-performing loans (NPL). When creditor pressure comes, companies seek recovery primarily through financial restructuring. Where the company has a sustainable business perspective, it may shortly reach stability through financial restructuring. On the other hand, if we take into account the changes in market conditions and the structural issues most businesses need to address, corporate recovery is not possi- ble without introducing comprehensive changes and without implementing strategic, operational and financial measures.

In view of the above, for a successful corporate recovery to take place changes have to be timely initiated and comprehensive restructuring measures have to be implemented. Turnaround management encompasses all these measures.

Corporate restructuring may be performed through courtled restructuring proceedings i.e. under the Bankruptcy Law or through a voluntary process.

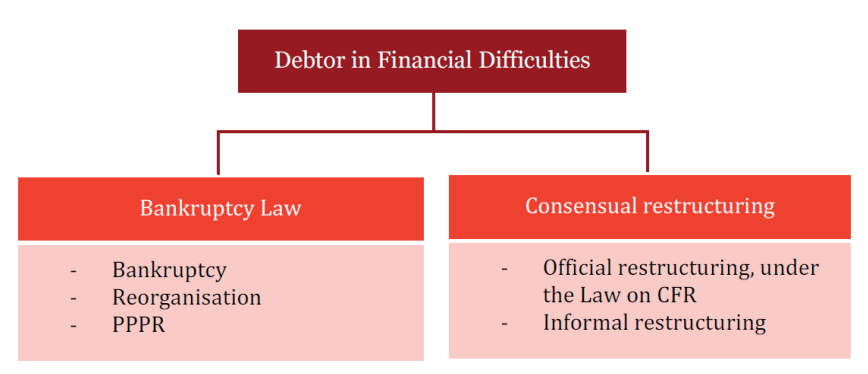

Bankruptcy involves settling obligations towards creditors by selling all assets of the debtor, or selling the legal entity.

Reorganisation aims at settling obligations towards creditors in accordance with the adopted Plan of reorganisation. Where the Plan of reorganisation is filed together with the Proposal to initiate bankruptcy proceedings, the name of the Plan is changed into Pre-Packaged Reorganization Plan. 
Consensual restructuring may be implemented under the Law on Consensual Financial Restructuring (CFR) or independently, irrespective of the a specific legal framework (informal restructuring).

Each of the aforementioned models, exclusive of the bankruptcy, makes the implementation of financial, strategic and operational measures possible. Opting for a certain model depends on a number of factors, such as the stage of the crisis, the company's future perspective, and the level of trust between the debtor and its creditors.

\section{TURNAROUND CASE STUDY - GENERALI INSURANCE, ITALY}

The first step in a successful turnaround is to identify the company's potential for improvement and to rationalise its business operations. The next step is to prepare the Implementation Plan and to implement the recovery program. Periodical reviewing of the results achieved is aimed at measuring the success of the recovery program, and at identifying corrective actions that will bring further improvement in the future. A successful recovery program most often entails investing cash and engaging experts in various fields.

Favourable results may be achieved provided that all the steps are optimally implemented, which implies engaging specialists from each of the company's "lines of service", the Administration, Procurement, Production, Sales, Finance, and from other lines of service. One of the critical success factors for implementing the recovery program is appropriate coordination of activities, which should be performed by a Manager with multidisciplinary skills (the Chief Restructuring Officer/ CRO) or by a Team of Managers, depending on the planned volume of activities and the size of the company. A competent manager will be trained to integrate financial and non-financial information relevant for the recovery of the company, to convert such information into plans and tasks, and to ensure the timely monitoring of the status of all activities.

If we say that there is potential for improvement in every area of operations, it will not turn out that we have been wrong.

Strategic decision-making calls for a detailed analysis of the expected market trends; a thorough understanding of the stages of a product's life cycle and the effects of the socio-economic factors and applicable laws. In addition to defining a company's operations strategy linked to its key activities and market, successful restructuring cannot go without having all or most of the company's processes optimised (production, procurement, sales, finance, human resources etc.).

The Plan for Future Sales derives from a company's strategy, and is considered a cornerstone in planning inventory and product volume levels. For finished goods to be available to customers in accordance with the Plan for Future Sales, it is essential that raw materials are secured in a timely manner and that the production process warrants optimum utilization of all resources.

For example, if we take the procurement procedure, the first question that arises is whether the company has a clear and transparent purchasing policy in place. If the company does have a clear and transparent purchasing policy in place, the second question that arises is whether this policy is good enough and in which of its segments there is room for im- provement. For procurement management to be carried out more efficiently, the company may consider establishing various policies and procedures such as: Supplier Selection Policy, the effects of which are reflected in choosing and doing business with reliable and reputable suppliers; Centralised Procurement Policy at the level of individual and group purchasing; Policy on Long-term Contracts with Key Suppliers with a view to securing lower prices and better purchasing terms and conditions.

When it comes to sales and collection procedures, significant savings and the freeing up of cash can be achieved by establishing appropriate policies with respect to: the credit policy based on which the terms (number of days) and the levels (limits) of deferred payments to be granted to company customers are defined; customer segmentation by size and importance, based on which more favourable sales terms for key customers are defined; the billing process that ensures timely delivery of error-free invoices; the trade receivables collection procedure that clearly defines employees' duties and responsibilities, including incentives for successful collection of accounts receivable.

The Finance Function has an important role in activating internal resources. Employees within the Finance Department play a key role in generating a large number of reports that are daily used by management in their decisionmakings. According to the a research recently conducted in Great Britain, reports prepared by finance department are one of the management's top priority. However, the quality of these reports was rated as unsatisfactory, as $80 \%$ of the respondents said that the reliability and the accuracy of financial projections are essential for planning financing needs, whereas only $45 \%$ are confident in the reliability of their own reports. Furthermore, the interviewed managers said that in addition to the traditional role of the finance function, which is to provide management with support in the financial reporting process, they require from their employees to take part in making strategic decisions and finding opportunities to increase profitability. This trend should not be surprising. Given the nature of their work, finance managers are familiar with all aspects of business and are able to participate in the centralisation of financial and non-financial information which isused in strategic decision-making and in defining the key performance indicators.

The success of the recovery cannot be measured in the short term. According to Slatter's theory (Slatter et al., 2012), the restructuring process can be considered successful if pretax profit rises over four out of six years (as of the crisis) (Jeremić, 2014).

Very often, the turnaround process is accompanied by personnel and organisational changes (Jeremić, 2014). One of the critical factors in this process is employee quality. Investing in talented employees is one of the key aspects of turnaround management. Quite often, the turnaround process is accompanied by personnel and organisational changes (Jeremić, 2014). Furthermore, adequate technical support i.e. adequate software solutions will significantly contribute to the success of the program.

Corporate restructuring arises from the company's need to return as a market player and the very approach depends on whether the company is developed or underdeveloped. The case study below presents a once developed company whose competitiveness deteriorated due to the financial crisis, leaving the company short of liquid assets. 


\section{Case Study: Generali Insurance}

The observed period starts in 2012, the year when Mario Greco took on the role of Generali's CEO, so that the company could regain its position and reputation in the midterm period (by 2017).

Generali was the Europe's third largest insurance company by premiums, however, as of 2008 when the crisis broke out, the company became unstable due to decreased liquidity.

The first measure introduced in 2012, following the identification of weakness and the analysis of operations and balance sheet data, was the reduction of operating costs. The program envisaged that by 2016 costs were to be reduced by approximately EUR 1 billion.

The first operating results for 2013 showed that the company has generated a net profit of EUR 1.92 billion compared to EUR 94.0 million generated in 2012.

The second significant measure introduced by the company was related to its investment policy, which was not centralized and led to unstable financial operations during the crisis. The company's decision to sell a portion of its investment portfolio which does not fall under the company's core activity, initially raised suspicion about the ultimate positive outcome. Mario Greco decided to sell investments worth EUR 2.4 million out of EUR 4 billion by 2015 (Institutional Investor, 2015):

1. Share in Migdal Insurance and Financial Holdings was sold in 2012 to Eliahu Insurance for EUR 705.0 million.

2. Share in Generali USA Life Reassurance was sold in 2013 to the French reinsurer SCOR for USD 910.0 million.

3. Share (49\% ownership) in the Mexican insurer Seguros Banorte was sold in 2013 to Mexican bank Grupo Financiero Banorte for USA 858.0 million.

4. The most recent major sale (the sale of a share in the Swiss Bank) has been postponed until the issue of the Treasury Department concerning US citizens tax evasion is resolved.

By selling its assets, Generali acquired a significant investment potential which was directed towards winning new eastern markets. The decision to sell its financial assets was primarily influenced by poor returns on the one hand and the need to settle its liabilities and make new investments on the other hand (Generali, 2015a).

The third measure was to change the types of insurance products. Turnaround Management was aimed at increasing the number of life insurance products against non-life insurance products so as to achieve a 50:50 ratio. To that end, the company developed unit-linked products which enabled clients to make bigger profits. In this way, the company has gradually restored confidence amongst their clients as well as its market reputation (Generali, 2015b).

\section{SUMMARY}

Having summarized the turnaround management results, it may be concluded that:

- The changes in management (concentration and centralisation) have been made.

- Improvements have been made to the company's life insurance portfolio, which stabilised the company's market share in Europe.

- The stabilisation of operations aimed at generating income from the company's core activity by increasing the company's market share through a diversified life insurance portfolio.

The Generali Insurance case study shows that by a turnaround management strategy which was consistently implemented, the company achieved the planned positive results. The focus of operations was returned to the company's core activity, which is to generate income and improve liquidity through investments and the balanced business policy.

For a successful change management, it is most important to engage an experienced external specialist.

\section{REFERENCES}

Generali. (2015a). Discorso CEO AGM E. Retrieved September 7, 2015 from www.generali.com

Generali. (2015b). 2014 Life EV Supplementary Information. Retrieved September 7, 2015 from http://www.generali. com/doc/jcr:8b4f9a5a-aa7c-4f8e-99d6-37c3877423e7/ lang:it/2014\%20FY\%20Life\%20EV\%20PDF.pdf

Gilson, S.C. (2010). Creating value through corporate restructuring: Case studies in bankruptcies, buyouts, and breakups. Hoboken, NJ: Wiley.

Institutional Investor. (2015). Mario Greco Restores Focus, and Profits, at Italy's Generali. Retrieved September 7, 2015 from http://www.institutionalinvestor.com/Article. aspx?ArticleId $=3344490 \& p=4 \# . V j U y \_W Q v d o k$

Jeremić, Lj. (2014). Savremeni menadžment zaokreta: razvoj i investiranje. Međunarodna naučna konferencija iz oblasti informacionih tehnologija i savremenog poslovanja, str. 648 - 651. Beograd: Univerzitet Singidunum.

Slatter, S.S.P., Lovett, D., \& Barlow, L.(2012), Leading Corporate Turnaround: How leaders Fix Troubled Companies. Hoboken, NJ: Wiley.

\section{TURNAROUND MANAGMENT KAO MODEL UPRAVLJANJA KORPORATIVNIM OPORAVKOM}

\footnotetext{
Apstrakt:

Tokom svetske ekonomske krize veliki broj kompanija pretrpeo je ogromne gubitke, a mnoge su doživele i poslovni krah. Promenjene tržišne okolnosti, nelikvidnost i interne slabosti zahtevaju sveobuhvatne promene. Turnaround menadžment, odnosno model upravljanja zaokretom, pokazao se kao dobar pristup u sprovođenju mera ozdravljenja kompanija koje se suočavaju sa ozbiljnim finansijskim i strukturnim problemima. Veliki broj kompanija različitih delatnosti koristi ovaj model, a u radu ćemo prikazati jedan takav model koji je ostvario dobar rezultat u vidu brzog finansijskog oporavka.
}

\author{
Ključne reči: \\ menadžment zaokreta \\ (turnaround management), \\ restrukturiranje, \\ oporavak.
}

